\title{
Characteristic of the Three Pig Keeping Systems on Performance of Small-Scale Pig Farmers at Manokwari, West Papua
}

\section{Karakteristik dari Tiga Sistem Peternakan Babi pada Peternak Skala Rumah Tangga di Manokwari, Papua Barat}

\author{
D.A. Iyai and S.Y. Randa
}

Department of Animal Production

Faculty of Animal Sciences Fisheries and Marine Sciences

The State University of Papua. Jl. Gunung Salju, Amban

Manokwari - Papua Barat. Indonesia. 98314

e-mail: da.iyai@yahoo.com

(Diterima: 26 April 2011; Disetujui: 30 Mei 2011 )

\begin{abstract}
Pig keeping systems consisted of extensive, semi-intensive and intensive systems were studied to seek its performances on pigs and small-scale pig farmers. From six districts and 15 villages, 50 respondents were chosen. Characteristic of farmers and pig keeping systems were studied. Animal number used were 355 tails for measuring pig variables consisted of body weight, reproduction and herd size. Labor and experience were varied among the three pig keeping systems $(\mathrm{P}<0.05)$. Animal herd, farrowing rate, suckling piglet number and its body weight, weaned body weight and adult body weight were differ significantly $(\mathrm{P}<0.05)$ particularly on semi-penned pig keeping. Pig production efficiency and pig production productivity used as qualitative characteristic were not drawing animal efficiency and producivity.
\end{abstract}

Keywords: pig keeping system, performance, pig production efficiency, pig production productivity

\section{INTRODUCTION}

Performances of animal production per se and in its herds have correlation along with animal production systems (Devendra, 2006), animal genetic (Kanis et al., 2008) and strategic location where animal production are established. Animal production systems, particularly pig production, vary initially commenced from traditional to modern systems. Animal genetic has evidently played roles in creating adaptive physiological reproduction and production based on local circumstances and established pig keeping systems will be shown from its typical location, for instances location in adjacent of crop production and or kitchen are abundant.

Four pig keeping systems in Manokwari identified (Iyai, 2008). These pig keeping systems (PKSS) are specialized prominently based on biophysical resources existing in an area such as quality and quantity of water, suitable climate and feeding availability. The latter is more severe in determining pig farming systems, besides, taking into account, management production decision. Feeding is accounted for $70-80 \%$ of the total purchased production (Eusebio, 1980; Udo, 1988). Feeding pigs in urban versus rural areas are contrasting dependent on prior mentioned resources. The PKSs in urban areas depend on kitchen and disposal or swill-feed (Anil et al., 2006), the so called non-conventional feeds (NCFs) (Udo, 1997) and commercial feed. Moreover, the PKSs in rural areas inevitably consider abundantly local resources such as crops and residuals.

In free-ranging pig keeping, breeds used are mostly local and crossbreds beside wild (Sus scrofa) and crossed pigs. Local, wild crossed and crossed breeds raised in penned and semi-penned in Manokwari revealed also by Randa (1994) and Iyai 
(2008). Typical breeds raised in Manokwari are Dutch Landrace (Randa, 1994), White Landrace and China's pig. Iyai (2008) reported that pigs in Manokwari already have low production compared to other tropical countries, in which improved pigs are promoted such as in Vietnam (Lemke et al., 2006) and Thailand (Kunavongkrit and Heard, 2000). Information related to pig keeping systems, location and breed used was lagging behind. Therefore, this article was aimed to seek the performances of existing three pig keeping systems in Manokwari on performances of pigs and pig farmers at Manokwari, Papua Barat province of Indonesia.

\section{MATERIALS AND METHODS}

\section{Materials}

Study sites. The field study was done in Manokwari regency and involved six districts, i.e. Nothern Manokwari, Eastern Manokari, Western Manokwari, Warmare, Prafi and Masni district (Figure 1). Manokwari regency, which has a total area of $14,445 \mathrm{~km}^{2}$ and possesses a population of around 161,000 inhabitants with a density of 11,51 inhabitants $/ \mathrm{km}^{2}$, is located at $132^{\circ} 30^{\prime}-$ $134^{\circ} 45^{\prime}$ East Meridian and $0^{\circ} 20^{\prime}-2^{\circ} 25^{\prime}$ South latitude. Manokwari has relatively dense population of around 228 inhabitants per $\mathrm{km}^{2}$. The population in Manokwari is growing in both urban and rural areas, especially in transmigration areas, such as Prafi and Masni districts. Respondents chosen were guided by local extensionists, originated from 15 villages. In urban areas selected farmers originated from Anggrem, Borobudur, Fanindi, Wosi, Amban and Susweni villages, while in rural areas selected farmers origined at Tanah Merah, Nimbai, Waseki, Aimasi, Mokwan, Mimbowi, SP-8 Masni, Bremi and Warbefor villages. Three urban villages, Anggrem, Fanindi and Wosi, are situated on coastal areas of Manokwari as well as the two rural villages, i.e. Bremi and Warbefor, which are located in the Northern coastal line of Manokwari. Anggrem, Fanindi and Wosi are located at less than $5 \mathrm{~m}$ above sea level. Amban and Susweni are located at $110 \mathrm{~m}$ above sea level. The rural villages Bremi and Warbefor, are located less than 5 meter above sea level. While most villages in Prafi valley, such as Tanah Merah, Waseki, Nimbai, Aimasi, Mokwan, Mimbowi and SP8 are located at about 20 to 25 meter above sea level.

Animal sampling. A number of 355 pigs comprised of 106 piglets, 74 weaned piglets, 103 growers, 72 sows and 28 boars were observed and measured. Quantitative variables consisted of body weights $(\mathrm{kg})$, body lenght $(\mathrm{cm})$, hearth girth $(\mathrm{cm})$, litter size (n), borned piglet body weight $(\mathrm{kg})$, farrowing size (yr) were measured.

\section{Methods}

Research approach and parameters. Participatory situation analysis (PSA) was employed to approach pig farmers (Conroy, 2005). Interviews using questionnaire was done to gather information from all pig farmers. Pig body weights were weighed using $20 \mathrm{~kg}$ digital weighing except for mature pigs, body lengths and hearth girths were measured using tape. Body weight predictions were done using equation of Walter (2007), i.e. BW $(\mathrm{Kg})=\frac{(L \times G \times G)}{137819(\mathrm{~cm})}$, where $\mathrm{BW}$ is body weight; $\mathrm{BL}(\mathrm{L})$ is body length $(\mathrm{cm})$ and $\mathrm{HG}(\mathrm{G})$ is hearth girth $(\mathrm{cm})$. Herd number (in Topical Livestock Unit, TLU), number of piglets, adult pigs, mortality, body condition scores (BCS), body weight, body length, hearth girth. Tropical livestock unit (TLU) of the pig is 0.25 from body weight. The PPP and PPE are indicators of pig production systems used by Chiduwa et al. (2008). Pig production potential (PPP) is calculated as $\mathrm{PPP}=\left(\frac{M}{P P E}\right) \times 100$, where $\mathrm{M}$ is number of growers and mature pigs consumed and/or sold. Pig production efficiency (PPE) is computed as PPE $=$ (sum of weaning piglets, grower, sows and boars)/total herd. 
Statistical analysis. A one-way analysis of variances (Ott and Longnecker, 2001) was used. Classification was based on pig keeping systems (Iyai, 2008). Mathematical formula was $Y i j=\mu+\alpha i+\varepsilon i j$, where $\mathrm{Y} i j$ is variable responses consisted of herd number (in Topical Livestock Unit, TLU), number of piglets, adult pigs, mortality, body condition scores (BCS), body weight, body lengths, hearth girth, pig production potential (PPP), and pig production efficiency (PPE); $\mu$ is overall mean, $\alpha i$ is effect of pig keeping systems, and $\varepsilon i j$ is errors with normal distribution, $\mathrm{N}$ $(0, \mathrm{I})$. Qualitative and quantitative data were entered in excel database (2003). Analysis of data using SPPS version 10.0 was used. The logarithmic normal (Ln) and square-root (sqrt) were used in checking of normality and due to non-normality data of PPE and PPP, Kruskal-Wallis Test was run.

\section{RESULTS AND DISCUSIONS}

\section{Features of Pig Farmers in The Pig Keeping Systems}

In the unpublished report of Iyai (2008), four pig keeping systems were classified in Manokwari, i.e. free-range pig keeping system (FRPKS), restrained pig keeping system (RPKS), semi-penned pig keeping system (SPPKS) and penned pig keeping system (PPKS). Seeing of these pig farming systems, it seems that restrained- pig keeping system (RPKS) can be incorporated into semi-penned by considering that the pigs still have chances to roam around, no shelter provided upon and pigs are tied up at stick adjacent backyard. Besides, no severe differences of the two pig keeping systems were drawn. In the subsequent paragraphs, results and discussion will be addressed on FRPKS, SPPKS and PPKS.

The findings shown that gender play a prominent role in small-scale pig keeping (Table 1.). Men played more prominent role as pig farmer manager in these three PKSs than women $(>50 \%)$. FRPKS and PPKS still had higher number of household members than SPPKS. Number of labors still was higher in SPPKS than the other two. No significance found amongst ages of these three pig keeping systems. Due to the fact that FRPKS is the old pig keeping system, higher number of year experiences found in the FRPKS than that of SPPKS and PPKS. The commencing years of the two pig keeping systems, SPPKS and PPKS, are not known yet.

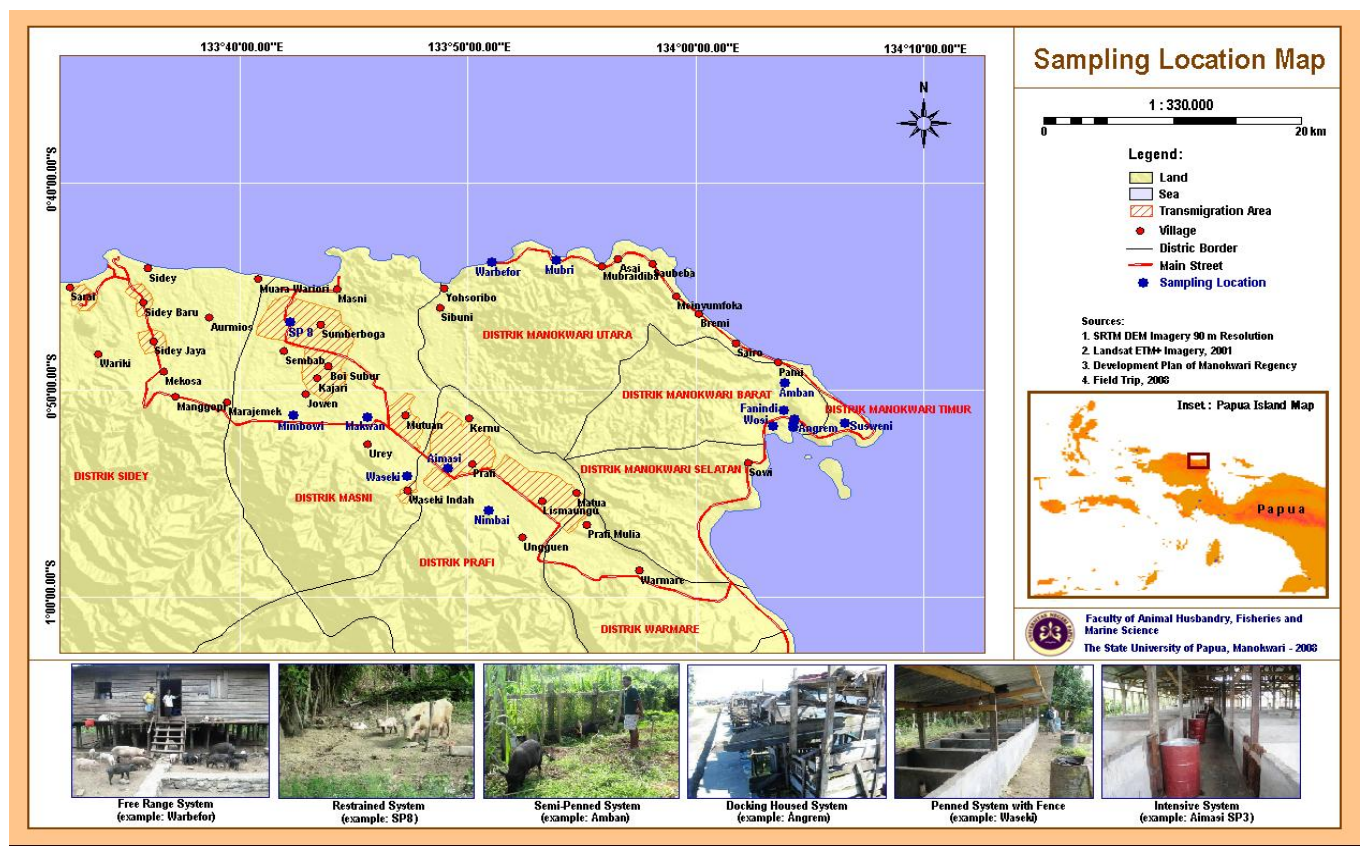

Figure 1. Study sites and samples of pig farming systems in Manokwari, Papua Barat Indonesia (Iyai, 2008) 
Table 1. Performances of pig farmers in the three pig keeping systems

\begin{tabular}{|c|c|c|c|c|c|c|c|c|}
\hline \multirow{3}{*}{$\begin{array}{l}\text { Indicators of } \\
\text { Performances }\end{array}$} & \multicolumn{6}{|c|}{ Pig Farming Systems } & & \\
\hline & \multicolumn{2}{|c|}{ FRPKS $(n=19)$} & \multicolumn{2}{|c|}{ SPPKS $(n=16)$} & \multicolumn{2}{|c|}{ PPKS $(n=15)$} & \multicolumn{2}{|c|}{ Total $(n=50)$} \\
\hline & Mean & SD & Mean & SD & Mean & SD & Mean & SD \\
\hline \multicolumn{9}{|l|}{ Gender (\%) } \\
\hline Men & 16 & 84 & 15 & 100 & 15 & 94 & 46 & 92 \\
\hline Women & 3 & 16 & 0 & 0 & 1 & 6 & 4 & 8 \\
\hline Hh. members (n) & 6.2 & 0.7 & 5.1 & 0.4 & 6.9 & 0.9 & 6.1 & 0.4 \\
\hline No. of labors (n) & $1.8^{\mathrm{a}}$ & 0.2 & $2.2^{\mathrm{b}}$ & 0.2 & $1.6^{\mathrm{a}}$ & 0.1 & 1.8 & 0.1 \\
\hline Ages (yr) & 47.9 & 2.2 & 47.1 & 3.2 & 40.4 & 3.1 & 45.3 & 1.7 \\
\hline Experiences (yr) & $30.9^{\mathrm{a}}$ & 3.2 & $21.2^{\mathrm{a}}$ & 3.2 & $14.3^{\mathrm{b}}$ & 4.1 & 22.7 & 2.2 \\
\hline \multicolumn{9}{|l|}{ Education $(\%)$} \\
\hline No education & 17 & 89 & 4 & 27 & 2 & 13 & 23 & 46 \\
\hline Basic education & 2 & 11 & 7 & 46 & 9 & 56 & 18 & 36 \\
\hline Higher education & 0 & 0 & 4 & 27 & 5 & 31 & 9 & 18 \\
\hline \multicolumn{9}{|l|}{ Sources of income $(\%)$} \\
\hline State officers & 5 & 26 & 3 & 20 & 4 & 25 & 12 & 24 \\
\hline Farmers & 13 & 68 & 11 & 73 & 5 & 31 & 29 & 58 \\
\hline Civil & 1 & 6 & 1 & 7 & 7 & 44 & 9 & 18 \\
\hline
\end{tabular}

Note: Superscripts differed in the rows shown significant differences(one-way Anova test, $\mathrm{P}<0.05$ )

Table 2. Pig farming performances in the three pig keeping systems

\begin{tabular}{|c|c|c|c|c|c|c|c|c|}
\hline \multirow{3}{*}{$\begin{array}{l}\text { Performance of Farming } \\
\text { Systems }\end{array}$} & \multicolumn{6}{|c|}{ Pig Farming Systems } & \multirow{2}{*}{\multicolumn{2}{|c|}{ Total $(n=50)$}} \\
\hline & \multicolumn{2}{|c|}{ FRPKS $(n=19)$} & \multicolumn{2}{|c|}{ SPPKS $(n=16)$} & \multicolumn{2}{|c|}{ PPKS $(n=15)$} & & \\
\hline & Mean & SD & Mean & SD & Mean & SD & Mean & SD \\
\hline $\operatorname{Herd} \operatorname{size}(\mathrm{n})^{1}$ & $1.5^{\mathrm{a}}$ & 0.9 & $3.3^{b}$ & 3.3 & $1.9^{\mathrm{a}}$ & 1.6 & 1.9 & 1.8 \\
\hline Farrowing frequency $(\mathrm{n} / \mathrm{yr})$ & 1.4 & 0.1 & 1.7 & 0.1 & 1.6 & 0.1 & 1.6 & 0.1 \\
\hline Littersize (n) & $5.3^{\mathrm{a}}$ & 1.7 & $6.7^{\mathrm{b}}$ & 2.1 & $5.1^{\mathrm{a}}$ & 2.7 & 5.7 & 2.2 \\
\hline \multicolumn{9}{|l|}{ Body weight $(\mathrm{kg})$} \\
\hline Piglets $(n=106)$ & $2.9^{\mathrm{a}}(\mathrm{n}=23)$ & 0.6 & $2.8^{\mathrm{a}}(\mathrm{n}=61)$ & 0.7 & $3.5^{\mathrm{b}}(\mathrm{n}=22)$ & 0.5 & 2.9 & 0.7 \\
\hline Weaned piglets $(n=74)$ & $13.2^{\mathrm{a}}$ & 2.1 & $14.9^{\mathrm{a}}$ & 3.4 & $15.9^{\mathrm{b}}$ & 2.1 & 14.4 & 2.9 \\
\hline Grower $(n=103)$ & $18.6^{\mathrm{a}}$ & 2.3 & $23.8^{\mathrm{b}}$ & 8.4 & $26.3^{\mathrm{b}}$ & 7.1 & 23.3 & 7.2 \\
\hline Sow $(n=72)$ & $54.2^{\mathrm{a}}(\mathrm{n}=29)$ & 8.9 & $65.9^{b}(n=24)$ & 13.8 & $77^{c}(\mathrm{n}=19)$ & 26.4 & 64.1 & 18.9 \\
\hline $\operatorname{Boar}(n=28)$ & $60.5(n=8)$ & 8.2 & $65.6(n=7)$ & 9.7 & $85.3(n=13)$ & 30.4 & 73.3 & 29.3 \\
\hline
\end{tabular}

Note: $\quad{ }^{1}$ Number of animal in the Tropical Livestock Unit (1 TLU=0.25). There was a significant difference between pig body weight in pig keeping systems, One-way Anova test $(\mathrm{P}<0.05)$

For the cases of Manokwari, most smallscale farmers were found being no education. Less than 50\% small-scale pig farmers had higher education. Majority of income was contributed from farming (>50\%). While other findings revealed several farmers did work as state officers (20-25\%) and civilian.

FRPKS and SPPKS were mostly done by small-scale farmers. Changes of extensive pig keeping systems to more intensive pig keeping systems and its triggers are not monitored yet. Free-range pig keeping system has no effects raised on rural areas, while SPPKS has social constraints. Although it was projected that SPPKS has shown productivity and records, such as data in Table 1. Other experiences drawn from practicing pigs in the rest of Asian and African countries such as Thailand, Cambodia and India and Zimbabwe (Chiduwa et al., 2008 and Amaufule et al., 2006) show satisfying effect.

Free-range pig keeping systems, semipenned and penned pig keeping systems still have considerable animal production systems in Papua (Cargill and Mahalaya, 2007). 
Involvement of gender, particularly the ratio of man-woman, has shown responsibility. Similar finding was revealed by Nakai (2008) in hillside Thailand. Experiences in Colombia (Ocompo et al., 2005) shown that family nucleus was 8 persons per household. This is rather high as found in Manokwari. Ages of farmers are above average ages of productive workers in Indonesia, i.e. 17-50 years old.

Contrary with finding in Columbia reported by Ocompo et al. (2005), that ages were vary from 12 to 45 years old. Farmers seem having adequate experiences in Manokwari. Many experiences might be obtained from formal education, i.e. basic and higher educations. Iyai (2008) informs that information and technologies, such as local newspaper, FM radio broadcasting and other IT tools, are lagged behind. The role of informal education such as training and workshop are poorly available. This caused that although farmers have sufficient experiences their high motivation is not provided by related and important stakeholders as well, i.e. government and banks. Therefore, appropriate and handy innovations are absolutely needed to improve low production and reproduction of smallscale pig farming systems.

\section{Pig Performances}

Number of animals in tropical livestock unit was higher in SPPKS subsequently pursued by PPKS and FRPKS. The higher number of SPPKS was induced by the roles of gender, sum of household members, ages of farmers, experiences and working focuses according to this study. Farrowing frequency was still higher in SPPKS $(1.7 \pm 0.1)$ and followed by FRPKS and PPKS. Litter size was then higher in SPPKS $(6.7 \pm 2.1)$ and followed by FRPKS and PPKS, i.e. 5.3 \pm 1.7 and 5.1 \pm 2.7 , respectively.

Body weight of piglets was significantly higher in PPKS (3.5 \pm 0.5$)$ than these other two. This proper body weight of piglets provided good indicator for the subsequent growth phases, i.e. weaned, growers, sows and boars. These were shown good indicators for ideal pig keeping management. Weaned body weight was higher in PPKS $(15.9 \pm 2.1)$ than the other two. What this findings argued was that there was no recording provided by pig farmers. Growers obtained 23 to $26 \mathrm{~kg}$ of body weight in SPPKS and PPKS, respectively. Body weight of sows varied and was higher in PPKS. As in boars, contrast finding was found higher in PPKS than the other two.

In South East Asia no average reports of body weight are presented (Nakai, 2008). Hence, records every country is available, such as in India (Phookan et al., 2006), in Vietnam (Peters, 2001; Lemke et al., 2005; Lemke et al., 2006 and Roessler et al., 2008). Particular cases indeed contributed from Africa such as in Zimbabwe (Chiduwa et al., 2008) and Pacific countries (Saville and Manuelli, 2002). From Latin America examples of Columbia (Ocompo et al., 2005) that average body weight of weaned piglets was $7.6 \mathrm{~kg}$ which is lower than that in Manokwari, i.e. $>10 \mathrm{~kg}$. Gilt and boars had sdightly higher in Manokwari (refers to Table 2.) than in Columbia, i.e. 26 and $28 \mathrm{~kg}$. This proper body weight of piglets provided best indicator for the progeny growth phases, i.e. weaned, growers, sows and boars. The latter, the finding that only few numbers of boars found in every pig keeping system in Manokwari might be become the reason why productivity of the sow per se is low. As we know that almost all pig farmers in Manokwari use natural mating without AI. Estrus detection and experience in mating pigs become the requirement of farmers.

Keeping and gathering boars during mating seasons along with sows and gilts will improve and release estrus time and in turn follicle development, example in Thailand can be drawn by Am-in et al. (2010). Moreover, sows body weight can be a best indicator and has causal effects on dynamic of follicle growth and number of borned piglet. In fact valid data is needed to parameterize longevity rate of piglets up to weaned piglets and grower phases, such reported by Nakai (2008). 
Table 3. Pig production productivity and pig production efficiency in Manokwari

\begin{tabular}{|c|c|c|c|c|c|c|c|c|}
\hline \multirow{3}{*}{$\begin{array}{c}\text { Performance } \\
\text { of Pig Farming }\end{array}$} & \multicolumn{6}{|c|}{ Pig Farming Systems } & \multirow{2}{*}{\multicolumn{2}{|c|}{ Total $(n=46)$}} \\
\hline & \multicolumn{2}{|c|}{ FRPKS $(\mathrm{n}=17)$} & \multicolumn{2}{|c|}{ SPPKS $(n=14)$} & \multicolumn{2}{|c|}{ PPKS $(n=15)$} & & \\
\hline & Mean & SD & Mean & SD & Mean & SD & Mean & SD \\
\hline $\mathrm{PPP}^{\mathrm{n} . \mathrm{s}}$ & 0.97 & 0.12 & 0.86 & 0.21 & 0.85 & 0.21 & 0.89 & 0.18 \\
\hline $\mathrm{PPE}^{\mathrm{n} . \mathrm{s}}$ & 200 & 86.6 & 246.29 & 123.52 & 293.84 & 182.78 & 244.69 & 137.94 \\
\hline
\end{tabular}

* n.s: not significant (Kruskal-Wallis Test, $\mathrm{P}>0.05$ )

Missing records of farmers will lead to inappropriate data management for research and development. Litter size in Thailand traditional pig keeping systems (Nakai, 2008) was higher (7.1) than that in Manokwari, which only had 6.7. While litter size after weaning is 6.7 with mortality is $16 \%$. High number of litter size could be reached in Columbia, i.e. on average litter size of 9 (Ocompo et al., 2005). Number of farrowing was slightly similar found under this pig keeping systems, i.e. 2 times $\mathrm{y}^{-1}$. Similar findings were reported in India by Kumaresan et al. (2007) and in Vietnam by Lemke and Zarate (2008). The finding of this author revealed that no seasonality of farrowing found in hillside Thailand. In developing countries putting pig as animal agricultures, productivity of pig per se and in flock (herds) will have adequate improvement such as done in India, Thailand and Vietnam.

\section{Productivity and Efficiency of Pig Production}

One important indicator of production systems is by measuring pig production, productivity and its efficiency (Chiduwa $e t$. al., 2008). Table 3 depicts PPP and PPE of pig keeping systems in Manokwari. Due to outliers of several data and in order to avoid bias, total numbers of represented pig farmers were purposively reduced.

The PPP was intended to measure and provide data of sold and consumed pigs with life pigs. Table 3 shown that pig production productivity (PPP) was slightly similar in these three pig keeping systems. PPE wants to draw efficiency of pigs in line with herd size productivity. High score efficiency of pig production (PPE) was achieved by
SPPKS (246.29 \pm 123.52$)$ and followed by FRPKS and PPKS. In this study, piglets were purposively taken-off due to the longevity of born pigs. The FRPKS in developing countries has high mortality case, low offtake and low reproduction rate (Kagira et al., 2010). These findings of PPP and PPE were similar either in free-ranges, semi-penned and penned pig keeping systems.

Economic parameters then should be incorporated in this field research in drawing the contribution of pig keeping systems into achievements of pig farming performances such as reported by Nakai (2008). Pig farmers should keen of the two basic indicators of Pig Production Productivity and Pig Production Efficiency (Chiduwa et al., 2008). The PPE and PPP are the two recording systems that show flowing performances of efficiencies of pig farming recording and wide utilization. Other parameters can be seen in Kovac et al. (1994). The width of utilization will have significant worthwhile effect in household livelihood. The ideal productivity (PPP) and efficiency (PPE) should be achieved by intensive pig keeping in reality. However, this achievement was not able proven by penned pig keeping system. Designing management pig production via physiological ages of pigs will enable farmers for allocating needed resources. Farmers will know how many animals they keep, herds (flock) dynamic they have and be practical in replacement programs.

\section{CONCLUSIONS}

Characteristics of the three pig keeping systems evidently contribute on pig farmers performances and pig productivity. This 
shown by several adequate parameters, such as experiences, household members, etc.. Many achievements of pig productivity are met and provided by semi-penned pig keeping systems. Although, economically it seems that this needsfurther intensive research to seek dynamic productivities of these pig keeping systems. Besides, characteristics assumed inducing effects on pig performances need further study.

\section{ACKNOWLEDGEMENT}

This field research was done under financial support of NUFFIC-NESO scholarship programs and Wageningen University - DLO, The Netherlands. Special thanks are given due to helps of Stafanus, Jhon and Mansar Korwa and farmers' collaboration during collecting data.

\section{CITED REFERENCES}

Amaufule K.U., S.N. Ibe, S.F. Abasiekong and O.C. Onwudike. 2006. Response of weaner pigs to diets of different proportions and high levels of palm kernel meal and brewer dried grain in the humid tropics. Pakistan Journal of Nutrition, 5 (5), 461-466.

Am-in, N., W. Tantasuparuk and M. Techakumphu. 2010. Comparison of artificial insemination with natural mating on smallholder farms in Thailand, and the effects of boars stimulation and distance of semendelivery on sowreproductive performance. Trop. Anim. Health Production, 42, 921-924.

Anil, K.S., P.C. Saseendran, J. Mathew and M. Murugan. 2006. Effect of management systems on growth performance of two genetic groups of pigs. Tamilnadu J. Veterinary and Animal Sciences, 2 (6), 229-233.

Cargill, C. and S. Mahalaya. 2007. Farmbased multidisciplinary research to improve pig production efficiency in the Papua Province of Indonesia. P: 6474. Pig systems in Asia and The Pacific; how can research and development benefits to the poor? Proceedings of a Regional Workshop. 23-24 November 2006. Bangkok, Thailand. W. Thorpe and Tesfayeh Jemaneh (Eds). ILRI Proceedings. http://mahider.ilri.org/bitstream/10568/ 1741/4/ Pig Systems_Pacific_Asia_ Final. pdf.

Chiduwa G., M. Chimonyo and T.E. Halimani. 2008. Herd dynamic and contribution of indigenous pigs to the livelihood of rural farmers in a semiarid area of Zimbabwe. Tropical Animal Health Production, 40, 125136.

Conroy, C. 2005. Participatory livestock research; a Guide. ITDG publishing. Warwickshire. United Kingdom.

Eusebio, J.A. 1980. Pig production in the Tropics. Intermediate tropical agriculture series. W.J.A. Payne (Ed). Longman Group Ltd. Essex. United Kingdom.

Devendra, C. 2006. Perspectives on animal production systems in Asia: Review Article. Journal of Livestock Science, 105, 229-242.

Iyai, D.A. 2008. Innovation possibilities in pig keeping systems in Manokwari, Papua Barat province-Indonesia. MSc. Thesis. Wageningen University.

Kagira, J.M., P.W.N. Kanyari, I. Maingi, S.M. Githigia, J.C. Ng'ang'a, J.W. Karuga. 2010. Characteristic of the smallholder free range pig production systems in Western Kenya. Trop. Anim. Health Production, 42, 865-873.

Kanis, E., K.H.D. Greef, A. Hiemstra and J.A.M.V. Arendonk. 2008. Breeding for societally important traints in pigs. J. Anim. Sci., 83, 948-957

Kovac, M., A. Salehar and M. Drobnic. 1994. Assessment of reproduction 
efficiency in swine. Satellite Symposium on Pig Management Information Systems. S. Martin Rillo, A. Aumaitre, L. Den Hartog, G. Backus, P. Glodek, F. Saiz and A. Salehar (eds). Proceedings. 12 September 1992. Ministerion De Agricultura, Pescay Y Alimentacion. Madrid, Spain.

Kumaresan, A., K.M. Bujarbaruah, K.A. Pathak, B. Chhetri, S.K. Das, A. Das and S.K. Ahmed. 2007. Performance of pigs reared under traditional tribal low input production system and chemical composition of non-conventional tropical plants used as pig feed. Livestock Science, 107, 294-298.

Kunavongkrit, A. and T.W. Heard. 2000. Pig reproduction in South East Asia. Animal Reproduction Science, 60-61, 527-533.

Lemke, U., L.T.T. Huyen, R. Robler, L.T. Thuy and A.V. Zarate. 2005. Impact of the use of exotic compared to local pig breeds on socio-economic development. Proceeding. Tropentag 2005. Conference on International Agriculture Research and Development. Stuttgart-Hohenheim. October 11-13 2005. Germany.

Lemke, U., B. Kaufmann, L.T. Thuy, K. Emrich, A.V. Zarate. 2006. Evaluation of smallholder pig production systems in North Vietnam: pig production management and pig performances. Livestock Science, 105, 229-243.

Lemke, U. and A.V. Zarate. 2008. Dynamics and developmental trends of small holder pig production systems in North Vietnam. Agricultural Systems, 96, 207-223.

Nakai, S. 2008. Reproductive performance analysis of native pig smallholders in the hillside of Northern Thailand. Trop. Anim. Health Prod., 37, 501-511.

Ocompo, L.M., P. Leterme and A. Buldgen. 2005. A survey of pig production systems in the rain forest of the pacific coast of Columbia. Trop. Anim. Health Prod., 37 (4), 315-326.

Ott, R.L. and M. Longnecker. 2001. An introduction to statistical methods and data analysis. $5^{\text {th }}$ Edition. Texas A \& M University. Wadsworht Group, USA.

Peters, J. 2001. Local human-sweet potatopig systems: characterization and research in Irian Jaya, Indonesia with limited reference to Papua New Guinea. A $2^{\text {nd }}$ Literature Review. "Poverty Alleviation and Food Security through improving the Sweet PotatoesPig Systems in Indonesia and Vietnam" International Potato Center (CIP).

Phookan, A., S. Laskar, A. Aziz, and R.N. Goswami. 2006. Reproductive performance of indigenous pigs of the Brahmaputra valley of Assam. Tamilnadu Journal of Veterinary and Animal Science, 2 (4), 121-125.

Randa, S.Y. 1994. Performance of indigenous pigs of upland and lowland Irian Jaya. Thesis. Department of Animal Science. Los Baños, The Philippines.

Roessler, R., A. G. Drucker, R. Scarpa, A. Markemann, U. Lemke, L.T. Thuy and A.V. Zarate. 2008. Using choice experiments to assess smallholder farmers' preferences for pig breeding traits in different production systems in North-West Vietnam. Ecological Economics, 66 (2008), 184-192.

Saville, P. and P. Manueli. 2002. Pig production in the Pacific island countries and territories. ACIAR Working Paper No. 53. March 2002. Australian Center for International Agriculture Research. Canberra, Australia.

Udo, H.M.J. 1997. Relevance of farmyard animals to rural development. Outlookon Agroculture, 26(1), 25-28. 
Udo, H.M.J. 1988. Pig production in the Tropics. Department of Tropical Animal Production. Lecture Notes. Wageningen Agricultural University, The Netherlands.
Walter. 2007. How to Weigh a Pig with a String. Sugar Mountain Farm. 31 July 2008. http://sugarmountain.com/blog/ 2006/01/how-to-weigh-pig-withstring.html 